\title{
Social Integration Dynamics for Migrants: PIAAC to Measure Skill and Qualification Mismatch
}

\author{
Bonacci Manuela", Mineo Simona \\ INAPP - National Institute for Public Policies Analysis - Corso d'Italia, 33 - 00198 Roma, Italy
}

Copyright $\mathrm{O} 2018$ by authors, all rights reserved. Authors agree that this article remains permanently open access under the terms of the Creative Commons Attribution License 4.0 International License

\begin{abstract}
This paper aims at highlighting the overlapping between the qualification mismatch and the skill mismatch, using a specific Italian data set drawn from PIAAC survey (2012). The main concern, regarding skills and competences, is that they may be gathered and accumulated, but also potentially become obsolete, thus, qualifications (formally recognized) do not necessarily correspond to used skills and competences. Measuring skill mismatch is evidently problematic as there are not many direct information regarding skills at the workplace. Usually information comes from self-reported measures (correspondence of tasks performed at work) or comparing indicators of proficiency and use at work,

times more likely than natives to be under-skilled in literacy. And the difference arises if we consider the time parameter (since how long they have been living in Italy): less than 5 years residents are even more under-skilled (more than 30\%). Besides, foreign workers are overqualified $(26.5 \%)$ much more than Italians $(12.4 \%)$ and also two times more likely to be over-qualified than natives. But it is worth noting that among overqualified workers (with a higher qualification than the one needed to carry out the specific job), foreign workers seem to lack the necessary skills. This discrepancy is an important element to understand social integration dynamics and thus orientate policies.
\end{abstract} methodologies prone to bias. Skill mismatch arises from several structural modifications in countries economy and social demographic events such as migration. And skill mismatch and qualification mismatch are a common phenomenon among foreign workers. The levels of both their qualifications and the skills used at work are rarely well-match among this particular target group. Besides, the Italian system not always is able to adequately assess, recognize and validate qualifications and/or skills and competences possessed by immigrants who are applying for working positions. PIAAC makes it possible to compare qualifications, information processing skills (literacy and numeracy) and skills required on the job, for specific target groups. The Survey of Adult Skills provides a measure of skill mismatch: it arises when workers have higher or lower skills proficiency (measured) than that required by their jobs (self-reported information). The relationship between skill mismatch and labour market outcomes involves different approaches and implications at policy level in inclusive societies, especially considering economic and socio-demographic factors. Among the three proficiency cognitive domains of PIAAC, we focused on literacy mismatch as (compared to numeracy) is a parameter of high relevance for the chosen target group (migrants). In fact it indicates the adaptability in the host working context due to language difficulties. Findings in PIAAC show that foreign workers are three
Keywords Qualification Mismatch, Skill Mismatch, PIAAC, Migrants

\section{Introduction}

This paper aims at highlighting the overlapping between the qualification mismatch and the skills mismatch, using a specific Italian data set drawn from PIAAC survey (2012), considering that qualification match does not necessarily mean skill match.

Measuring skill mismatch is evidently problematic, as there are not many direct information regarding skills at the workplace. Usually information comes from self-reported measures (correspondence of tasks performed at work) or comparing indicators of proficiency and use at work, methodologies prone to bias.

PIAAC makes it possible to compare qualifications, information processing skills (literacy and numeracy) and skills required on the job, for specific target groups.

The Program for the International Assessment of Adult Competencies (PIAAC) is a cyclical, large-scale study, developed under the umbrella of the Organization for Economic Cooperation and Development (OECD). Adults were surveyed in 24 participating countries in 2012 (first 
cycle - Round 1) and 9 additional countries in 2014 (Round 2) and further 6 countries in Round 3 (2016-19).

The goal of PIAAC [1] is to assess and compare the basic skills and the broad range of competencies of adults around the world. The assessment focuses on cognitive and workplace skills, needed for successfully participate in the 21st-century society and the global economy. Specifically, PIAAC measures relationships between individuals' educational background, workplace experiences and skills, occupational attainment, use of information and communications technology and cognitive skills in the areas of literacy, numeracy, and problem solving.

The Survey of Adult Skills provides a measure of skill mismatch: it arises when workers have higher or lower skills proficiency (measured) than those required by their jobs (self-reported information). The relationship between skill mismatch and labour market outcomes involves different approaches and implications at policy level in inclusive societies, especially considering economic and socio-demographic factors.

PIAAC is based on:

- a background questionnaire, gathering information on the participants' generic and workplaces skills and personal characteristics as well as their socio-economic background, occupations and skills used at the workplace;

- an internationally harmonized test, assessing the cognitive domains in: literacy, numeracy and problem solving in technology-rich environments [2]. These skills constitute "key competences" in many social and work-related contexts. They are highly significant to fully integrate individuals in the society and the labour market.

The target group of adults (16-65) for the survey were the non-institutionalized individuals, who lived in the country at the time of the data collection (2011-12), regardless of nationality, language spoken or citizenship.

Among the three proficiency cognitive domains of PIAAC, we focused on 'literacy' mismatch as (compared to numeracy) is a parameter of high relevance for the chosen target group (migrants). In fact, it indicates the adaptability in the host working context, due to language difficulties.

In the case of migrants in PIAAC, it is methodologically necessary to take into account that the sample was not designed to identify a number of respondents statistically fully significant. It was not a specific sampling, but it resulted from the residence selection. It is important to note that foreigners who have responded to PIAAC survey are considered "integrated migrants", i.e. individuals who interact regularly with institutions, have a stable residence address and have a good command of Italian language, thus they can actively take part in the daily life of the country. They belong to the main communities of foreigners resident in Italy
(Romanians, Moroccan, Albanian, Chinese, Ukrainian and others) and the sample estimated in PIAAC is $9.2 \%$ of the total sampling, corresponding to approximately 3.645 .907 individuals, aged 16 to 65 years. Istat ${ }^{1}$ estimated that in 2012 foreigners resident in Italy was 4.387.721 [3].

The phenomenon of immigration is rapidly changing its characteristics, due to short-term effects such as the acceptance and integration policies of receiving countries and factors linked to the socio-political dynamics of the countries of origin (wars, opening of borders, socio-economic instability, etc.).

These global characteristics, combined with some peculiarities of Italy (such as the strong component of undeclared work and the more general phenomenon of illegal presence/entrance) represent a challenge, not only in terms of security, but also in terms of welfare, working conditions and integration. In fact, in recent years, social dynamics addressed to migrants, in Italy, have involved various levels of decision-making, from the legislative domain of the central state, to the support of local authorities, which are responsible for activating active policies and social integration.

\section{Methodology}

The selected methodology [4] employed a consequential approach by: a) considering qualification mismatch and skills mismatch concepts and their indicators individually; b) identifying over-qualification and under-skilling trends for the entire sampling; c) focusing on over-qualification and under-skilling trends for migrants; recognizing overlaps and trends.

By using this approach we intended to associate mismatch trends with target dynamics, identifying priority groups, due to target characteristics (age, gender, migrants, parental situation ...) and specific labour market conditions (part-time, temporary/permanent contracts) and, although it varies across the different types of mismatch, different trends may be acknowledged.

Mismatch becomes a relevant structural indicator, in the following PIAAC rounds, to monitoring over-qualification and under-skilling trends, in order to adapt policies and strategies for priority groups.

If a good match between skills required by enterprises and those acquired through learning pathways (formal and non-formal contexts) is important to promote strong and inclusive social and economic growth; the methodology used in PIAAC gives direct information regarding key competences and skills required at workplace.

In this direction the objectives of the present analysis, aimed at identifying those elements (mismatch) useful to

1 Istat - Istituto Nazionale di Statistica (the Italian National Institute of Statistics) http://www.istat.it/en 
support social interventions for better inclusion and integration towards migrants (learning activities, guidance and work placement initiatives, experiences of integration between active labour policies and social policies, etc.).

\section{Definitions and PIAAC Concepts and Measures}

It is relevant to identify how "qualification" mismatch and "skills" mismatch are addressed and defined in PIAAC [5].

Qualification mismatch is the measure of the qualification level required at work and the qualification possessed by the worker.

PIAAC survey asks workers to report the qualification they consider necessary to get their job today. However it is important to note that this measure combines current and past qualifications as it reflects the qualifications of people who have been hired at different times.

The question is:

"If applying today, what would be the usual qualifications, if any that someone would need to get this type of job"?

Table 1. Measures of qualification mismatch

\begin{tabular}{|c|c|c|}
\hline \multirow{1}{*}{$\begin{array}{c}\text { Qualification } \\
\text { mismatch }\end{array}$} & Mismatch concept & Measure used in PIAAC \\
\hline \multirow{1}{*}{ Over-qualification } & $\begin{array}{c}\text { A worker is classified as } \\
\text { over-qualified when the } \\
\text { difference between his or her } \\
\text { qualification level and the } \\
\text { qualification level required } \\
\text { in his or her job is positive }\end{array}$ \\
\cline { 2 - 3 } & Under-qualification & $\begin{array}{c}\text { A worker is classified as } \\
\text { under-qualified when the } \\
\text { difference between his or her } \\
\text { qualification level and the } \\
\text { qualification level required } \\
\text { in his or her job is negative }\end{array}$ \\
\cline { 2 - 3 } & Well matched & $\begin{array}{c}\text { There is a well match when } \\
\text { the worker's qualification } \\
\text { level and the qualification } \\
\text { level required in his or her } \\
\text { job is the same (equal) }\end{array}$ \\
\hline
\end{tabular}

Source: OECD Survey of Adult Skills (PIAAC) (2012)

Skills mismatch is defined as the gap between the portfolio of skills possessed by workers and the package of skills required for a specific occupation.

When there is a lack of skill-balance, there is a high risk that the labour market does not operate efficiently, thus having an effect on the unemployment rates. Besides, skill mismatch has an impact on the individual and company level, as it affects wages, job satisfaction and turnover [6-8].

In PIAAC the measures of skill mismatch are identified by using micro-level data, through:

- quantitative information obtained by the assessment of skill proficiency with an internationally harmonized test, based on a questionnaire assessing the cognitive skills of individuals in three domains: literacy, numeracy and problem solving in technology-rich environments.

- qualitative information - i.e. self-reported information through the following two questions:

A. Do you feel to "have the skills to cope with more demanding duties than those you are required to perform in your current job"?

B. Do you feel you "need further training in order to cope well with your present duties"?

When the answers to both $\mathrm{A}$ and $\mathrm{B}$ questions are negative (NO), they are considered "well matched" in their occupation in their country.

This group of respondents - considered "well matched" - are used to create a quantitative scale of the skills required to perform their job for each occupation (based on 1-digit ISCO $\operatorname{codes}^{2}$ ).

Using this scale of proficiency scores (0-500) of well-matched workers, minimum (5th percentile) and maximum (95th percentile) threshold values are identified.

To compute the OECD measure of skills mismatch, workers are classified over-skilled in a domain if their score is higher than the maximum threshold of self-reported well-matched workers, and they are under-skilled in a domain if their score is lower than the minimum threshold of self-reported well-matched workers.

Table 2. Measures of skills mismatch

\begin{tabular}{|c|c|c|}
\hline & $\begin{array}{c}\text { Mismatch } \\
\text { concept }\end{array}$ & Measure used in PIAAC \\
\hline \multirow{4}{*}{$\begin{array}{c}\text { Skills } \\
\text { mismatch }\end{array}$} & $\begin{array}{c}\text { Over-skilling in } \\
\text { the domain }\end{array}$ & $\begin{array}{c}\text { When a worker's proficiency is } \\
\text { higher than the 95th percentile. }\end{array}$ \\
\cline { 2 - 3 } & the domain & $\begin{array}{c}\text { When a worker's proficiency is } \\
\text { lower than the 5th percentile. }\end{array}$ \\
\cline { 2 - 3 } & Well matched & $\begin{array}{c}\text { When a worker has a proficiency } \\
\text { within these bounds }(5<\text { score }<95)\end{array}$ \\
\hline
\end{tabular}

Source: OECD Survey of Adult Skills (PIAAC) (2012)

So, the measure of skills mismatch combines information about skill proficiency, self-reported mismatch and skill use. The skills mismatch is expressed in an excess or deficit of skills [9, 10], identifying minimum and maximum skill requirements for each occupation (1-digit ISCO codes) and to classify workers into three groups: well matched, under-skilled and over-skilled.

The incidence of Qualification mismatch [11] in PIAAC for "Literary" domain is as showed in Figure 1.

2 Using 1-digit ISCO codes (International Standard Classification of Occupations) is the main limitation of this measure as it assumes that all jobs with the same occupation code have the same skill requirements. 


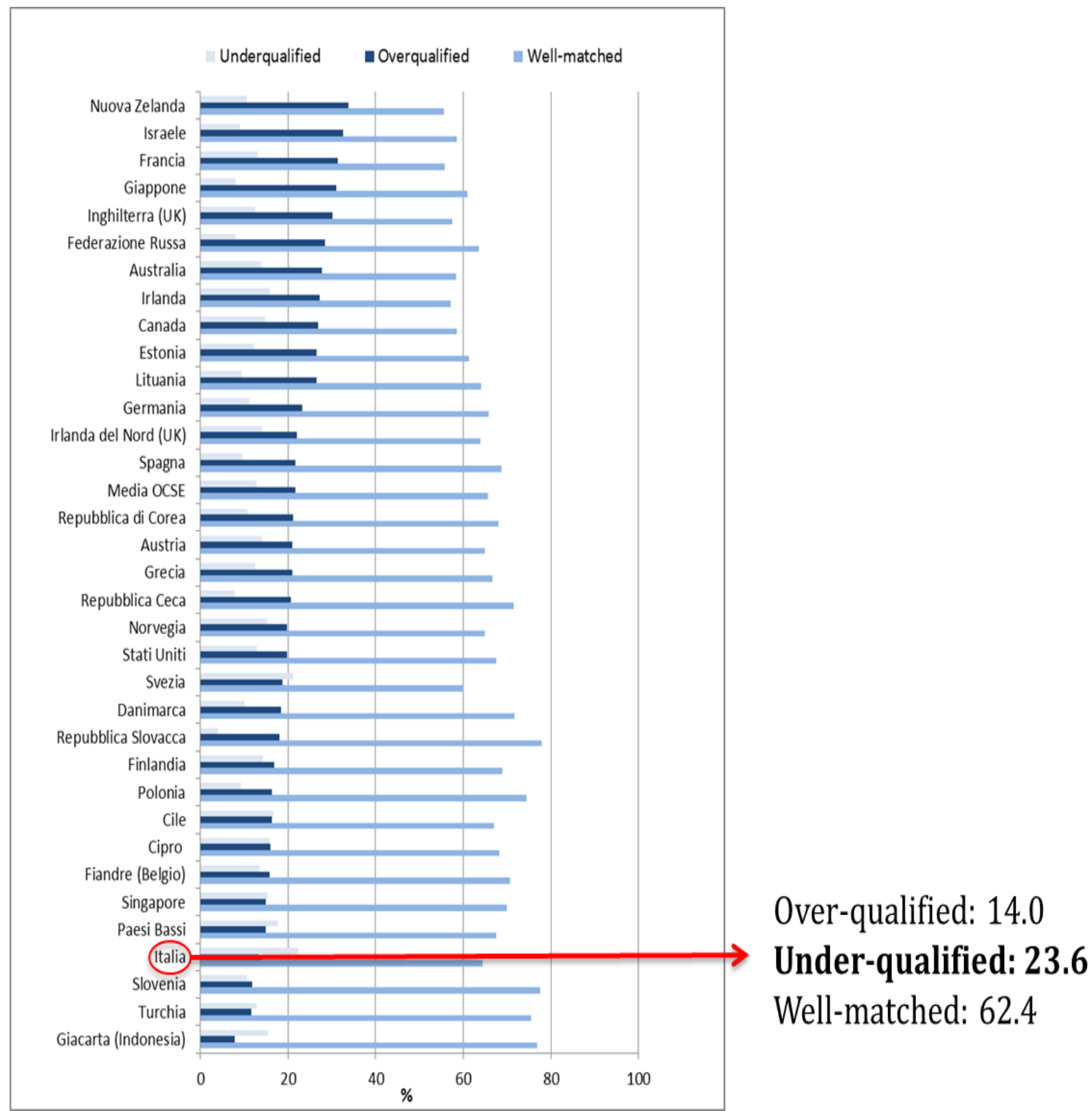

Source: OECD Survey of Adult Skills (PIAAC) (2012)

Figure 1. Percentage of workers in each category of qualification mismatch (in Literary domain)

In PIAAC Italy is the country with the highest percentage of under-qualified workers.

According to PIAAC roughly one-third of workers in OECD countries are over- or under-qualified for their jobs.
Being over-qualified is, on average, approximately twice as common as being under-qualified.

The incidence of skills mismatch [11] in PIAAC for "Literary" domain is as showed in Figure 2. 


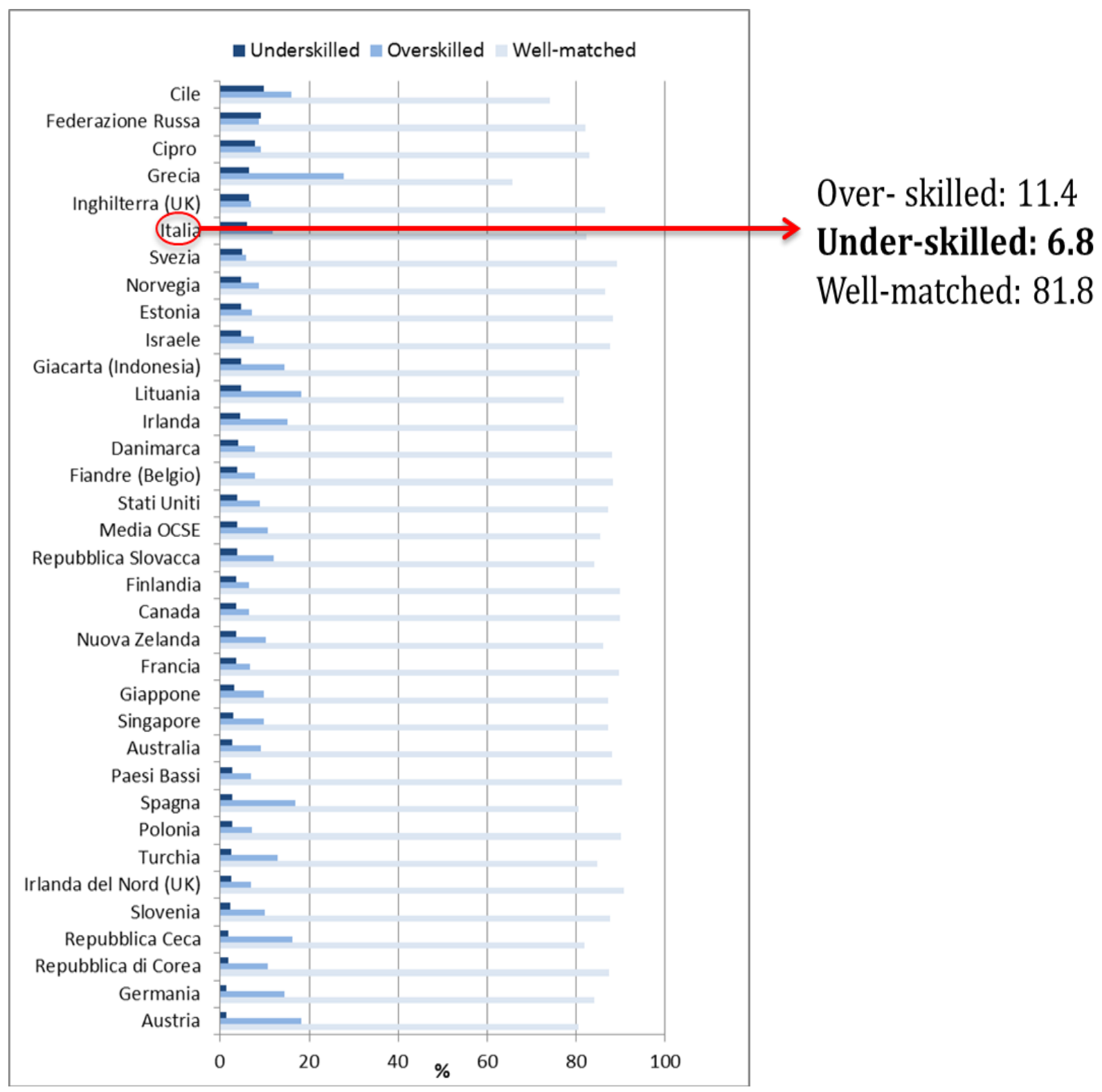

Source: OECD Survey of Adult Skills (PIAAC) (2012)

Figure 2. Percentage of workers in each category of skills mismatch (in Literary domain)

In PIAAC, for the under-skilled workers the highest percentages are registered in Chile (9.9\%), Russia (9.2\%) and Cyprus (7.9\%). Anyway Italy too registered a high percentage of under-skilled people.

According to PIAAC one-sixth workers report a mismatch between their existing skills and those required for their job [12].

Being over-skilled is, on average, two and a half times more common than being under-skilled.

The incidence of mismatch in Italy, compared to the average of OECD for "Literary" domain is as showed in Table 3 .
In the first PIAAC round (2011-12) Italy is the country with the highest percentage of under-qualified workers (23.6) while the OECD average is around 12.9.

However, data significant for social inclusion dynamics and labour market outcomes refer to both over-qualification and under-skilling measures.

In fact, if we detail the incidence of mismatch in Italy by place of birth, we identify trends significant to control these variables for this kind of target group, deeply affecting European economy in terms of labour market dynamics, plus inclusion policies in single country's civil societies, in terms of adequate Education and VET systems. 
Table 3. Percentage of workers in each category of qualification and skills mismatch (Italy vs. OECD average)

\begin{tabular}{|c|c|c|c|c|c|c|}
\hline \multicolumn{2}{|c|}{} & \multicolumn{2}{c|}{ Qualification Mismatch } & \multicolumn{2}{c|}{ Skills Mismatch } \\
\hline & Over-qualified & Under-qualified & Well-matched & Over-skilled & Under-skilled & Well-matched \\
\hline Italy & 14.0 & 23.6 & 62.4 & 11.4 & 6.8 & 81.8 \\
\hline OECD average & 21.4 & 12.9 & 65.8 & 10.3 & 3.6 & 86.2 \\
\hline
\end{tabular}

Source: OECD Survey of Adult Skills (PIAAC) (2012)
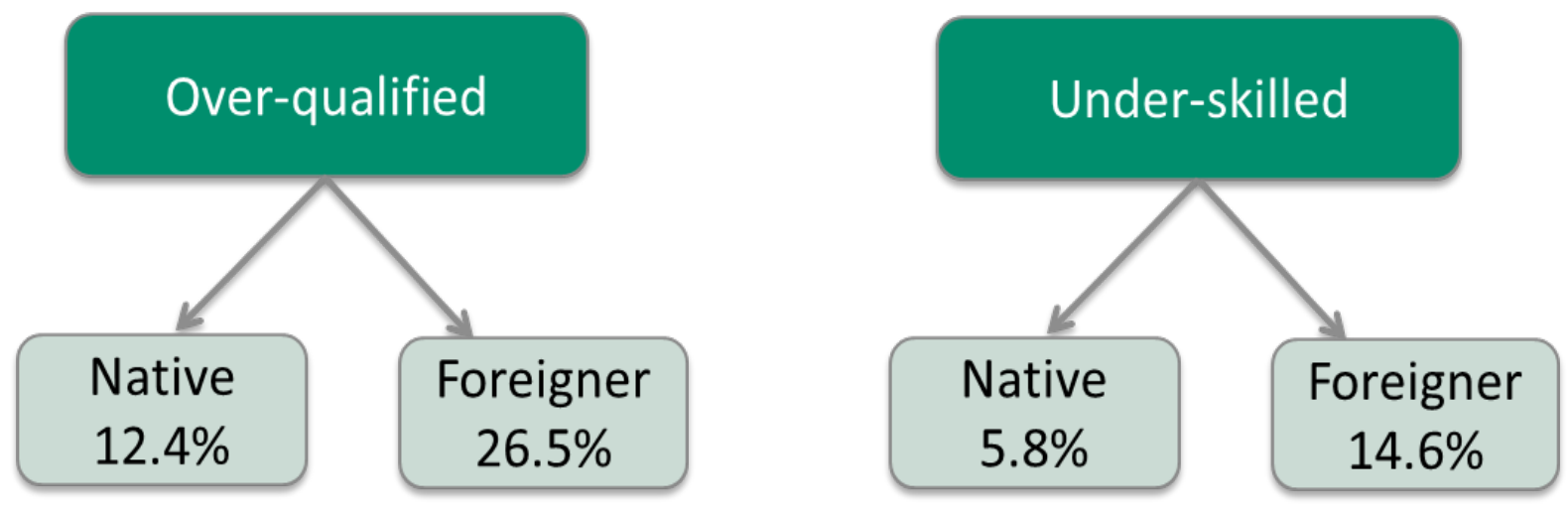

Source: OECD Survey of Adult Skills (PIAAC) (2012)

Figure 3. Incidence of Mismatch in Italy by place of birth

Foreign born workers are more likely to be over-qualified and under-skilled than native counterparts.

The perception of the foreign-born of having an educational level that exceeds the one required by the job they have, is higher than native workers.

A good match between the skills demanded by enterprises and those acquired in education and training systems and/or on the job (all learning contexts) may have a strong impact on inclusive policies and economic growth.

So, at a first glance, this implies that there is ground for improvement in OECD countries in terms of systems leading to the achievement of adequate qualifications and skills.

It is interesting to contrast qualification mismatch with skill mismatch.

\section{Data Analysis}

\section{Over-qualification Model}

Qualifications are the formal outcome of an assessment and validation process which is obtained when a competent body determines that an individual has achieved learning outcomes to given standards.

(European Union, 2008).

Our first objective was to evaluate whether the (self-assessed) over-qualification measure is related to personal socio-demographic characteristics, which, in turn, reflects national labour market conditions.

Thus, in the table below, there are the results of the logistic regression analysis which includes a selection of both: socio-demographic characteristics (white characters of the first column) and labour market conditions (written in black in the first column).

The socio-demographic variables have been tested individually and labour market control variables have been included. 
Table 4. Likelihood of over-qualification for workers in Italy by socio-demographic and job characteristics

\begin{tabular}{|c|c|c|c|c|}
\hline & \multicolumn{4}{|c|}{ Dependent variable: Over-qualified } \\
\hline & Variables & $\beta$ & Odds-ratio & \\
\hline \multirow[t]{3}{*}{ Age of respondent } & Younger workers (16-24) & 0.236 & $1.266 * * *$ & [0.005] \\
\hline & Prime-age workers (25-54) & 0.877 & $2.405^{* * *}$ & [0.003] \\
\hline & Older workers (55-65) & Ref. & & \\
\hline Gender & Woman & 0.214 & $1.238 * * *$ & [0.002] \\
\hline \multirow{2}{*}{$\begin{array}{l}\text { Background according } \\
\text { highest level of education's } \\
\text { parents }\end{array}$} & Disadvantaged background & Ref. & & \\
\hline & Advantaged background & 0.629 & $1.876^{* * *}$ & [0.002] \\
\hline Immigration status & Migrants & 0.747 & $2.111^{* * *}$ & [0.002] \\
\hline \multirow{4}{*}{$\begin{array}{l}\text { Occupational classification } \\
\text { (ISCO) }\end{array}$} & Skilled occupations & Ref. & & \\
\hline & Semi-skilled white collar occupations & 0.517 & $1.676^{* *}$ & [0.002] \\
\hline & Semi-skilled blue collar occupations & 0.508 & $1.662^{* *}$ & {$[0.002]$} \\
\hline & Elementary occupations & 0.599 & $1.821^{* *}$ & [0.003] \\
\hline \multirow[t]{2}{*}{ Hours worked } & Full time & Ref. & & \\
\hline & Part-time & 0.217 & 1.243 & [0.002] \\
\hline \multirow[t]{2}{*}{ Type of contract } & Indefinite & Ref. & & \\
\hline & Other & 0.343 & 1.409 & [0.002] \\
\hline
\end{tabular}

Source: OECD Survey of Adult Skills (PIAAC) (2012)

Note: Standard errors are reported in parenthesis and the stars denote significance level (*** at $1 \%$, level $* *$ at $5 \%$ level and $*$ at $10 \%$ level).

Individual and job characteristics may influence the likelihood of qualification mismatch and findings can be rationalized by arguing, for example, that:

\section{Age of respondent}

-Young workers (16-24) are more likely to be overqualified than older (55-65). But also prime age workers (25-54) are more likely to be overqualified than older.

It seems that older workers have acquired a better qualification match. The reason may lie on the fact that they have entered the labour market during a less difficult period (20-30 years ago) in terms of working positions available.

\section{Gender}

- Women are more likely to be overqualified than men. Regarding youth and women (vulnerable groups) there may be a (personal) need to accept jobs with a lower level of qualification, in order to combine family commitments and working activities. Or, another reason may be linked to the labour market, in which jobs offered/available are usually less qualified ones.

\section{Background according to parents' education level}

- the parental background influences the educational level of individuals. Workers having parents with an advantaged background are more likelihood to be overqualified than those with disadvantaged ones (which is of course an expected trend). Parents with a disadvantaged background are considered those without a secondary education diploma.

\section{Immigration status}

- migrants are two times more likely to be over-qualified than natives.

This finding needs to be further analysed and it probably depends on migration flows. Besides qualification mismatch among immigrants is a quite common phenomenon, as in this case qualifications can often not be adequately assessed or recognized.

\section{Occupational qualification}

- decreasing the level of the occupation (ISCO) it increases the likelihood of being over-qualified. So, workers employed in elementary occupation are more likely to be over-qualified than those enrolled in skilled occupation. The gap between white collar and blue collar (Table 4 - 1.6), referred to skilled workers, is less incisive than the elementary occupation (Table $4-1.8$ ). 
Table 5. Likelihood of over-qualification for MIGRANTS in Italy by socio-demographic characteristics

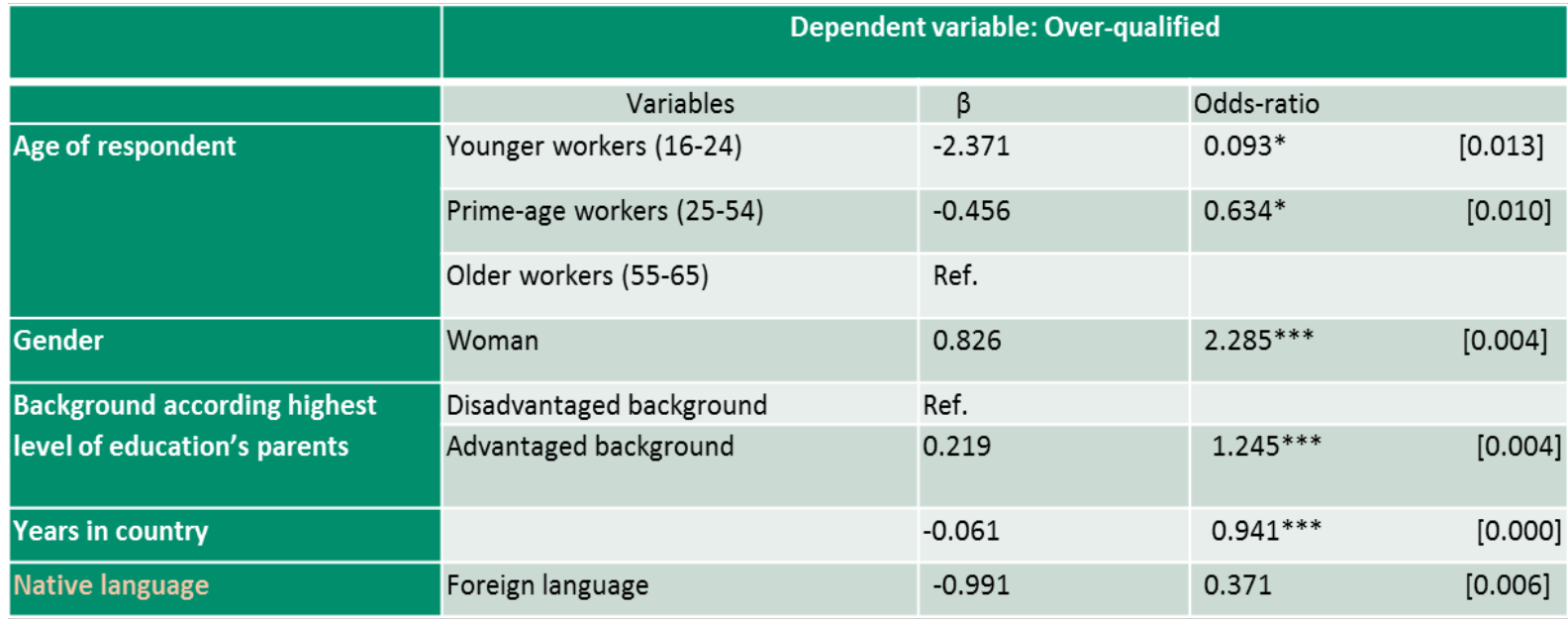

Source: OECD Survey of Adult Skills (PIAAC) (2012)

Note: Standard errors are reported in parenthesis and the stars denote significance level (*** at $1 \%$, level ** at $5 \%$ level and * at $10 \%$ level).

\section{Hours worked and type of contract}

Even if in the model there are not statistically significant results, we can note a specific Italian situation.

In fact, in some countries part-time jobs and non-permanent contracts are usually associated with lower qualifications. In Italy the situation is unusual. Non-permanent jobs are quite widespread in all sectors and qualifications levels. Even the apprenticeship contract may address higher qualifications (such as Master degrees or $\mathrm{PhD}$ ). Thus, the explanation of these findings is directly linked to the labour market offer. It will be very interesting to control these data in the future rounds, to see how the trend will change and if the "Jobs Act ${ }^{3}$ reform" has an impact on these variables.

When considering the whole dataset it is clear that being a migrant has a significant relation to the probability of experiencing over-qualification.

In the following model we fully analysed explicitly the migrant condition in order to better understand all migrant characteristics that may influence the over-qualification incidence.

In this model "age" is less significant than other co-variates, such as permanence in the host country, for example.
Young people (16-24) and prime age workers (25-54) are less likely to be over-qualified than older ones.

We noted that young migrant workers are not more likely to be over-qualified than older migrants.

It seems that if the native workers' probability of being over-qualified decreases over his/her lifecycle, this is not the case for migrants.

Generally speaking, growing the age parameter, it increases the likelihood of over-qualification for migrants.

But, in this model, it is more significant the "years in country" parameter. For migrants, the odds of being over-qualified increases as years go by.

This means that over-education is a problem which affects migrants, not only during their integration process, but also in the long run. The same trend has been noted in Ireland and in the Netherlands [12].

Another important variable that usually plays a role in the probability of mismatch is whether the person's language corresponds to the one officially spoken in the host country. However, in this model results are not significant.

By including labour market variables, we can summarize significant dimensions specified in the following table: 
Table 6. Likelihood of over-qualification for MIGRANTS in Italy by socio-demographic and job-characteristics

\begin{tabular}{|c|c|c|c|c|}
\hline & \multicolumn{4}{|c|}{ Dependent variable: Over-qualified } \\
\hline & Variables & $\beta$ & Odds-ratio & \\
\hline \multirow{3}{*}{ Age of respondent } & Younger workers (16-24) & -2.052 & $0.128 *$ & {$[0.014]$} \\
\hline & Prime-age workers (25-54) & -0.294 & $0.745^{*}$ & {$[0.010]$} \\
\hline & Older workers (55-65) & Ref. & & \\
\hline Gender & Woman & 0.793 & $2.210^{* * *}$ & {$[0.004]$} \\
\hline Background according highest & Disadvantaged background & Ref. & & \\
\hline level of education's parents & Advantaged background & 0.289 & $1.335^{* * *}$ & {$[0.004]$} \\
\hline Years in country & & -0.053 & $0.948 * * *$ & [0.403] \\
\hline \multirow[t]{4}{*}{ Occupational classification (ISCO) } & Skilled occupations & Ref. & & \\
\hline & Semi-skilled white collar occupations & 0.345 & 1.412 & [0.610] \\
\hline & Semi-skilled blue collar occupations & 0.783 & 2.188 & [0.131] \\
\hline & Elementary occupations & 1.057 & $2.877^{* * *}$ & [0.676] \\
\hline \multirow[t]{2}{*}{ Hours worked } & Full time & Ref. & & \\
\hline & Part-time & -0.404 & 0.667 & [0.433] \\
\hline \multirow[t]{2}{*}{ Type of contract } & Indefinite & Ref. & & \\
\hline & Other & -0.042 & 0.959 & [0.376] \\
\hline
\end{tabular}

Source: OECD Survey of Adult Skills (PIAAC) (2012)

Note: Standard errors are reported in parenthesis and the stars denote significance level $(* * *$ at $1 \%$, level ** at $5 \%$ level and $*$ at $10 \%$ level).

It is worth noting that migrants with a low occupation level are nearly three times (Table $6-2.8$ ) more likely to be over-qualified than those employed in skilled occupations.

\section{Under-skilled Model}

\section{"Skills transform lives, generate propensity and promote social inclusion"}

(OECD, 2013)

Skills mismatch arises from several structural modifications in countries economy and social demographic events, such as migration. Skills mismatch and qualification mismatch are common phenomena among foreign workers. The levels of both their qualifications and the skills used at work are rarely well-match among this particular target group. Besides, the Italian system is not always able to adequately assess, recognize and validate qualifications and/or skills and competences possessed by immigrants while applying for working positions.

Evidences show that the unbalance of skills is rather persistent and it is related to personal socio-demographic characteristics, which, in turn, reflect national labour market conditions.

In the table below there are the results of the logistic regression analysis which includes a selection of both: socio-demographic characteristics (in white in the first column) and labour market conditions (in black). 
Table 7. Likelihood of under-skilling for workers in Italy by socio-demographic and job characteristics

\begin{tabular}{|c|c|c|c|c|}
\hline & \multicolumn{4}{|c|}{ Dependent variable: Under-skilled } \\
\hline & Variables & $\beta$ & Odds-ratio & \\
\hline \multirow[t]{3}{*}{ Age of respondent } & Younger workers (16-24) & 0.700 & $2.013^{* \cdots}$ & {$[0.004]$} \\
\hline & Prime-age workers (25-54) & Ref. & & \\
\hline & Older workers (55-65) & 1.029 & $2.797^{* * *}$ & [0.003] \\
\hline Gender & Woman & -0.299 & $0.741 * * *$ & [0.002] \\
\hline Immigration status & Migrants & 1.195 & $3.302^{* * * *}$ & {$[0.002]$} \\
\hline \multirow[t]{3}{*}{ Educational Level } & Low & 0.340 & $1.406 * * *$ & [0.003] \\
\hline & Medium & -0.542 & $0.582 * * *$ & [0.003] \\
\hline & High & Ref. & & \\
\hline \multirow[t]{2}{*}{ Hours worked } & Full-time & 0.604 & 1.830 & [0.003] \\
\hline & Part-time & Ref. & & \\
\hline \multirow[t]{2}{*}{ Type of contract } & Indefinite & Ref. & & \\
\hline & Other & 0.269 & 1.308 & [0.003] \\
\hline
\end{tabular}

Source: OECD Survey of Adult Skills (PIAAC) (2012)

Note: Standard errors are reported in parenthesis and the stars denote significance level (*** at $1 \%$, level ** at $5 \%$ level and * at $10 \%$ level).

Individual and job characteristics may influence the likelihood of skills mismatch and findings can be summarised as the following:

\section{Age of respondents}

-Young workers (16-24) are more likely to be under-skilled than prime-age workers (25-54); this trend is expected, as young workers are, obviously, less experienced.

Inexperienced (young) workers are often found in temporary and entry-level jobs, thus skills requirements are usually lower than older workers (over-skilled). As workers gain more experience - and are better able to identify and demonstrate (recognition process) their skills, by referring to past experiences (recognised by the labour market) - it becomes easier for them to move into jobs where they can adequately use their skills.

- Older workers are almost 3 times (2.7) more likely to be under-skilled than prime-age workers, even more than young people. This data is less expected and it probably refers to the obsolescence of skills or the difficulties to be updated.

When the under-skilling measure increases with age, it may suggest that it is not a temporary phenomenon which can be absorbed during a working life. As people grow older age-related inequities and exclusion from skills-related activities, may lead to difficulties in maintain a job.

\section{Gender}

- Men seem to be affected by under-skilling conditions more frequently than women.

A possible explanation of these data is that the skill mismatch is measured from the results achieved only in literacy. Looking at skill proficiency for gender in Italy there are no statistically significant gender differences (average score - women 250, average score men - 251), but reading also the co-variates occupational data (ISCO), we see that:

Table 8. Mean literacy proficiency by gender and type of occupation for workers in Italy

\begin{tabular}{|c|c|c|}
\hline & Men & Women \\
\hline Skilled occupation & 274 & 273 \\
\hline Semi-skilled white & 256 & 255 \\
\hline Semi-skilled blue & 235 & 244 \\
\hline Elementary & 230 & 230 \\
\hline
\end{tabular}

Source: OECD Survey of Adult Skills (PIAAC) (2012)

The only real difference in performance regards blue collar occupations where we note the highest incidence of under-skilling. 
Table 9. Incidence of skill mismatch among type of occupation (\% by column) for workers in Italy

\begin{tabular}{|c|c|c|c|}
\hline & Under-skilled & Well-matched & Over-skilled \\
\hline Skilled occupation & 31.3 & 29.6 & 57.5 \\
\hline Semi-skilled white & 23.0 & 28.8 & 22.4 \\
\hline Semi-skilled blue & 42.4 & 29.7 & 15.4 \\
\hline Elementary & 3.3 & 11.9 & 4.7 \\
\hline
\end{tabular}

Source: OECD Survey of Adult Skills (PIAAC) (2012)

Therefore, when the type of job variable is taken into account, the differences in how men and women use their skills at work could change: while women tend to be concentrated in certain occupations, they use their skills more intensively than those men who are employed in similar jobs.

On this concern a Cedefop note [14] states that: "It is not clear if gender affects skill mismatch. It is possible that women's higher turnover rates may lead employers, when hiring for particular jobs, to require higher ability from women relative to men" (under-skilled), adding also:

"But the evidence of skill mismatch being a more serious problem for women than for men is mixed among countries".

\section{Immigration status}

- foreign born migrants are more likely to be (3 times) under-skilled than natives. - So, minorities, such as migrants and new comers in the labour market, are more prone to get a job with lower requirements than their skill level.

\section{Educational level}

- low level workers are one and half time more likely to be under-skilled than graduates; medium level workers are less likely to be under-skilled than graduates (Table 7).

\section{Hours worked and type of contract}

These variables do not influence the under-skilling phenomena.

Having full-time working contracts increases the likelihood to be under-skilled as well as workers with non-permanent contract jobs, who are more likelihood to be under-skilled than those with a permanent contract job, but data are not significant.

When considering the whole dataset it is clear that being a migrant has a significant relation with the probability of experience under-skilling. So, we fully analysed the migrant condition in order to understand better other migrant conditions that could influence the under-skilling incidence.

Considering the variables of migrant target we note that the younger workers' likelihood to be under-skilled is significant and very high (Table $10-3.37$ ), higher than results from the whole data set (Table $7-2.0$ ), which is expected, but still noteworthy. While for older people, differently from the general situation, it seems that they are not affected by the obsolescence of skills; this is, maybe, linked to the specificity of the occupation.

Besides, regarding the permanence in the host country, when it is less than 5 years, the probability of being under-skilled increases significantly (Table $10-2.4$ ), without any direct connection with age of respondents in this variable.

Table 10. Likelihood of under-skilling for MIGRANTS in Italy by socio-demographic and job characteristics

\begin{tabular}{|c|c|c|c|c|}
\hline & \multicolumn{4}{|c|}{ Dependent varlable: Under-skllled } \\
\hline & Va ria bles & $\beta$ & Odds-ratio & \\
\hline \multirow[t]{3}{*}{ Age of respondent } & Younger workers (16-24) & 1.217 & $3.378^{* 0 *}$ & {$[0.006]$} \\
\hline & Prime-age workers (25-54) & Ref. & & \\
\hline & Older workers (55-65) & -1.368 & $0.255^{\circ+\infty}$ & {$[0.020]$} \\
\hline Gender & Woman & -0.054 & $0.948^{* 0 *}$ & {$[0.005]$} \\
\hline \multirow[t]{3}{*}{ Educatlonal Level } & Low & 0.786 & $2.195^{* * *}$ & {$[0.010]$} \\
\hline & Medium & 0.037 & $1.037^{* 0 *}$ & {$[0.010]$} \\
\hline & High & Ref. & & \\
\hline \multirow[t]{2}{*}{ Years In country } & In host country 5 or fewer years & 0.884 & $2.421^{* *}$ & [0.005] \\
\hline & In host country more than 5 years & Ref. & & \\
\hline Nathe language & Forelgn language & -0.140 & 0.870 & [0.010] \\
\hline \multirow[t]{2}{*}{ Hours worked } & Full-time & -0.003 & 0.997 & {$[0.006]$} \\
\hline & Part-time & Ref. & & \\
\hline \multirow[t]{2}{*}{ Type of contract } & Ind efinite & Ref. & & \\
\hline & Other & -0.327 & 0.721 & {$[0.006]$} \\
\hline
\end{tabular}




\section{Summarizing Model Data}

It is important to identify specific dynamics and mismatches of the specific target group of migrants. The interactions between economic and social integration, as well as between different dimensions of social integration, influence policymakers, in fact, decision makers are pushed to adopt more effective approaches to improve inclusion and overcome social divisions to generate social cohesion. As with economic integration, immigrants' social integration improves along with their years of residence in destination country. In this context, policies have some influence on social integration and possible negative effects may happen, in the longer term, if countries introduce low investments in human capital.

The real overlap impact is clearly shown in the above described models, where recent (less than 5 years' permanence) foreign born workers (without age distinction) are more likely to be over-qualified and more under-skilled. A synthesis of the two models' findings:

\begin{tabular}{|c|c|}
\hline $\begin{array}{l}\text { General model } \\
\text { over-qualification } \\
\text { Young workers are more } \\
\text { likely to be overqualified } \\
\text { than older; } \\
\text { Prime-age workers are } \\
\text { more likely to be } \\
\text { overqualified than older; } \\
\text { Elementary occupation } \\
\text { are more likely to be } \\
\text { over-qualified; }\end{array}$ & $\begin{array}{l}\text { Migrant workers over-qualification } \\
\text { Young migrants are less likely } \\
\text { to be overqualified than older; } \\
\text { Prime-age migrants are even } \\
\text { less likely to be overqualified } \\
\text { than older; } \\
\text { Recent (no age distinction) } \\
\text { migrants are more likely to be } \\
\text { over-qualified; } \\
\text { Elementary occupation are } 3 \\
\text { times more likely to be } \\
\text { over-qualified; }\end{array}$ \\
\hline $\begin{array}{l}\text { General model under-skilling } \\
\text { Young workers are more } \\
\text { likely to be under-skilled } \\
\text { than prime-age and older } \\
\text { (expected); } \\
\text { Older workers are almost } \\
\text { 3 times more likely to be } \\
\text { under-skilled than } \\
\text { prime-age (obsolescence } \\
\text { of skills); } \\
\text { Low education level - } \\
\text { more likely to be } \\
\text { under-skilled than } \\
\text { graduates. }\end{array}$ & $\begin{array}{l}\text { Migrants under-skilling } \\
\text { Young migrants are } 3 \text { times } \\
\text { more likely to be under-skilled } \\
\text { than prime-age; } \\
\text { Older workers are less likely to } \\
\text { be under-skilled than } \\
\text { prime-age; } \\
\text { Recent migrants are more } \\
\text { likely to be under-skilled than } \\
\text { stable migrants; } \\
\text { Low education level - more } \\
\text { likely to be under-skilled than } \\
\text { graduates. }\end{array}$ \\
\hline
\end{tabular}

\section{Conclusions}

The findings of these two models demonstrate how some target groups may be deeply affected by mismatch of qualifications and skills. In fact, mismatch is one factor that may direct policy and prevent social and economic difficulties at country level.

High rates of workers who are over-qualified and/or under-skilled correspond to a trend correlated with a labour market under its potentiality, in which enterprises and workers are not fully satisfied.

Besides, the high incidence of mismatch amongst youth and migrants, suggests that inclusive strategies need to be implemented.

In particular, there is no doubt that a good command of the language of the host country constitutes an important maybe the most central - factor of integration, not only in the labour market, but also to improve social inclusion. We note a specific feature of the immigration phenomenon in Italy that is the vast majority of immigrants do not speak or understand Italian upon arrival. For this reason, host country language training is generally the most important measure for immigrants in most OECD countries (this is not the case of France and UK of course) and Italy is no exception in this sense. As a result, in Italy, the Permanent Territorial Centres for Adult Education (CPIA - Centri Territoriali Permanenti per l'Istruzione degli Adulti) play an essential role in language skills learning. A high percentage of participants in these centres obtain a linguistic certificate at the end of the courses and the role of the CPIA should be further strengthened.

Access to the citizenship, in the host country, is another important element of the integration policy. In fact, naturalization tends to have a positive impact on the labour market of immigrants, through a series of means [15], such as the removal of institutional obstacles in the labour market. Longitudinal data from many OECD countries suggest that the achievement of the citizenship in the host country is associated with higher employment rates and better wages and, above all, it leads to more qualified jobs [15]. Since immigration in Italy has been mainly based on employment needs, it would be expected that naturalization will help the access to more qualified jobs. In fact, although the citizenship does not necessarily improve the employment situation of immigrants, some data show that naturalization is associated with a greater probability of having a more qualified job.

Besides, it is important that immigrants benefit from new frameworks for the validation of skills and competences in order to recognise the possessed learning outcomes.

More in general, having presented and clarified the consequences caused by skills mismatch, it appears to be increasingly interesting for decision makers to identify the grounds of mismatch in order to increase labour market conditions, which will be translated into economic growth.

Furthermore, it is important to understand the potentiality of qualification frameworks together with skills and competences [16, 17] recognition for both enterprises to be competitive (through up-to-date skilled workers) and the individuals, in terms of employability.

The main concern, regarding skills and competences, is that they may be gathered and accumulated, but also potentially become obsolete, thus, qualifications (formally recognized) do not necessarily correspond to used skills and competences.

In this context, we may consider that over-qualified 
workers may not have benefited from their "formal" qualification and/or their competences are less advanced than the expected ones (connected to the specific formal qualification). Or formal qualifications are not fully recognized by the Labour Market, whereas they are generally perceived less valid than working experience (even not certified).

On the other side, under-qualified workers may have acquired the necessary skills to perform their jobs, outside formal learning pathways, through work-based learning activities or on-the-job learning experiences, but they are not able to certify their skills.

Recently the issue of skills mismatch has gained importance for policy makers not only in OECD member countries, but also within European strategies, in particular the New Skills Agenda for Europe, adopted by the Commission on 10 June 2016, launched a series of actions to make the right training, skills and support available to people in the EU.

\section{REFERENCES}

[1] ISFOL. PIAAC - OCSE Rapporto nazionale sulle competenze degli adulti (a cura di Di Francesco G.). Roma ISFOL. Temi Et ricerche, 5. 2014

[2] OECD. Literacy, Numeracy and Problem Solving in Technology-Rich Environments. Framework for the OECD Survey of Adult Skills, OECD Publishing, Paris. 2012

[3] ISTAT. Italia in cifre. 2016

[4] ISFOL. Il Framework teorico del programma PIAAC. Metodologia e strumenti per la valutazione delle competenze degli adulti. Roma ISFOL. Temi Et ricerche, 4. 2014

[5] INAPP. Focus PIAAC: i low skilled in literacy. Profilo degli adulti italiani a rischio di esclusione sociale (a cura di S. Mineo. e M. Amendola). Roma INAPP. Paper; 7. 2018. Online available from http://oa.inapp.org/xmlui/bitstream/h andle/123456789/121/INAPP_Mineo_Amendola PIAAC_1 ow_skilled_literacy_2018.pdf? sequence $=1 \&$ isAllowed $=y$

[6] J. Allen, R. van der Velden. Educational mismatches versus skill mismatches: effects on wages, job satisfaction, and on-the-job search. Oxford University Press. 2001. Online available from https://cris.maastrichtuniversity.nl/portal/file
s/606099/guid-d259b85a-2cc2-49ae-b321-38b3b43fe817-A SSET1.0

[7] K. Mavromaras, S. Mahuteau, P. Sloane, Z. Wei. The persistence of overskilling and its effects on wages. Adelaide National Centre for Vocational Education Research. 2012 Online available from http://www.flinders.edu.au/sabs/nilsfiles/reports/The $\% 20$ Persistence $\% 20$ of $\% 20$ overskilling 20 12.pdf

[8] G. Quintini. Right for the Job: Over-qualified or Under-skilled?. OECD Social, Employment and Migration. Working Papers, No. 120, OECD Publishing, Paris. 2011. Online available from http://dx.doi.org/10.1787/skg59fcz3t kd-en

[9] CEDEFOP. The Skill Matching Challenge: Analysing Skill Mismatch and Policy Implications. Publications Office of the European Union. February 2010 Online available from http://www.cedefop.europa.eu/EN/publications/15275.aspx

[10] CEDEFOP. Skill supply and demand in Europe: medium-term forecast up to 2020. April 2010. Online available fromhttp://www.cedefop.europa.eu/EN/publicatio ns/15540.aspx

[11] ISFOL. Il secondo round dell'indagine OCSE PIAAC: Le competenze per vivere e lavorare oggi (a cura di Bastianelli M, Mineo S). Roma ISFOL. Research Paper, 34. 2016

[12] OECD. Skills Outlook 2013: First Results from the Survey of Adult Skills. OECD Publishing, Paris. 2013

[13] European Union. Recommendation of the European Parliament and of the Council of 23 April 2008 on the establishment of the European Qualifications Framework for lifelong learning 2008/C 111/01, Official Journal of the European Union. 23.04.2008.

[14] CEDEFOP. Skill mismatch in Europe. Briefing Note- 9023 EN, ISSN 1831-2411, European Centre for the Development of Vocational Training. June 2010. Online available from www.cedefop.europa.eu/files/9023_en.pdf

[15] OECD. Naturalisation. A Passport for the Better Integration of Immigrants?. OECD Publishing, Paris. 2011. Online available from: http://dx.doi.org/10.1787/9789264099104-en

[16] European Union. Recommendation of the European Parliament and of the Council of 18 December 2006 on Key Competences for Lifelong Learning. 2006/962/EC, Official Journal of the European Union. 30.12.2006.

[17] European Commission. New Skills for New Jobs; Anticipating and Matching Labour Market and Skill Needs. Luxembourg. 2009 